\title{
The effects of the 1996-2012 summer heat events on human mortality in Slovakia
}

\author{
Dalibor VÝBERČI a ${ }^{\text {, }}$ Marek ŠVEC a ${ }^{\text {a }}$ Pavol FAŠKO ${ }^{\text {a }}$, Henrieta SAVINOVÁ ${ }^{\text {b }}$ \\ Milan TRIZNA ${ }^{c *}$, Eva MIČIETOVÁd
}

\begin{abstract}
The impacts of summer heat events on the mortality of the Slovak population, both in total and for selected population sub-groups, are the foci of this study. This research is the first of its kind, focusing on a given population, and therefore one priority was to create a knowledge base for the issue and to basically evaluate existing conditions for the heat-mortality relationship in Slovakia. This article also aims to fill a void in current research on these issues in Europe. In addition to overall effects, we focused individually on the major historical heat events which occurred in the summers of 2007, 2010 and 2012. During the heat events, a non-negligible negative response in mortality was recorded and fatal effects were more pronounced during particularly strong heat events and periods which lasted for two or more days. In general, females and the elderly were the most sensitive groups in the population and mortality was characterized by several specific effects in individual population groups. The most extreme heat periods were commonly followed by a deficit in mortality, corresponding to a short-term mortality displacement, the pattern of which varied in specific cases. In general, displaced mortality appeared to compensate for a large part of heat-induced excess deaths.
\end{abstract}

Keywords: weather extremes, weather stress, heat events, mortality, Slovakia

\section{Introduction}

Heat is the deadliest of all atmospheric phenomena (Changnon et al., 1996; Sheridan and Kalkstein, 2004). Heat-related mortality can be defined as the incidence of deaths which would not occur in the absence of heat stress (Zaninović and Matzarakis, 2014). Only a small portion of heat-related deaths is caused directly by hyperthermic conditions (overheating, heatstroke, etc.); high temperatures, however, contribute to a more pronounced pathogenesis of other, in the end deadly illnesses, especially of the circulatory and respiratory systems (e.g. Keatinge, 2003; Kenney et al., 2014).

Possible negative impacts of hot weather on the health status of the human population came to light under the current conditions of a changing climate, expressed, inter alia, by increases in the general occurrence of very high temperatures. Even in Slovakia, the trends of long-term variability in characteristics of excessive heat stress have changed significantly (Labudová et al., in press) and this is also confirmed by the findings of several other studies (e.g. Faško et al., 2013; Kolláriková et al., 2013). It should be noted that after the dissolution of the Institute of Human Bioclimatology in Bratislava in 1994, however, research in the area of human biometeorology was practically nonexistent in Slovakia. Therefore, no new expert studies concerned with weather influences on the health status of the Slovak population were conducted. This contribution thus represents a pilot initiative in this area of research after two decades. Its parallel objective is to create a knowledge base for this research issue in Slovakia.
The paper focuses on the impacts of summer heat events on human mortality during a 17-year period, with the entire population of the Slovak Republic being the object of interest. Unfortunately, due to the extent of available mortality data, the analysis did not include some relatively recent exceptional heat situations. Such periods of prolonged hot weather occurred mainly in the summers of 1992 and 1994, during which mortality increased considerably in the neighbouring states, for example, in the Czech Republic (Kyselý, 2004) or in Poland (Kuchcik and Degórski, 2009). Even in the period analyzed in this study (1996-2012), however, several summers with remarkably long durations of heat events were recorded, in which the Slovak population was exposed to a number of extremely hot episodes. Our intention was to evaluate both overall mortality during the heat events, as well as during the major individual historical heat events and most severe summers. In the absence of research in this area, both approaches represent useful sources of information, e.g. for potential public health measures during severe heat episodes in the future. Apart from evaluating the magnitude of heat impacts, we have also focused on the evaluation of other selected aspects of the heat-mortality relationship. Because of the existing "spatial gap" in the research of this issue, we turned our attention to complex comparisons of our results with a summary of findings in a broader geographical context, mainly that of Central Europe.

\section{Theoretical background}

Under current climate conditions, the issue of high temperatures impacts on human mortality has received

\footnotetext{
${ }^{a}$ Comenius University Science Park, Rectorate of Comenius University in Bratislava, Bratislava, Slovakia

${ }^{\mathrm{b}}$ Department of Living Environment Hygiene, Public Health Authority of the Slovak Republic, Bratislava, Slovakia

${ }^{c}$ Department of Physical Geography and Geoecology, Faculty of Natural Sciences, Comenius University in Bratislava, Bratislava, Slovakia (*corresponding author, Milan Trizna: e-mail: trizna@fns.uniba.sk)

${ }^{d}$ Department of Cartography, Geoinformatics and Remote Sensing, Faculty of Natural Sciences, Comenius University in Bratislava, Bratislava, Slovakia
} 
greater attention from scientists, especially due to the occurrence of some unprecedented extreme heat waves. Recently, since 2000, the exceptional mortality crisis was caused by heat waves in the extremely hot summer of 2003 (Kosatsky, 2005; García-Herrera etal., 2010), in which Western and Southwestern Europe were most severely affected, mainly in the first two weeks of August. During that summer there were almost 75,000 excess deaths in 16 European countries, from Spain to Poland and from Denmark to Italy (Robine et al., 2008). France was particularly affected, with nearly 15,000 excess deaths recorded just during the strongest August crisis (Fouillet et al., 2006; Toulemon and Barbieri, 2008). According to de Bono et al. (2004), with regard to the number of victims, the summer heat waves of 2003 were one of the worst natural disasters in Europe in the last 100 years, and absolute worst in the last 50 years. It is logical that this so-called 2003 big European heat wave has become an example of what a typical heat wave in a warmer climate might be like (Gosling et al., 2009).

In the summer of 2010, another anomalously hot period affected the European part of Russia in particular. Here, according to some estimates, in comparison to previous years mortality increased by 54,000 cases in July and August, approximately 11,000 of which were in Moscow. Taking into account the size of the affected population, it is stated that this heat wave was 2.4 times more dangerous than the 2003 European heat wave (Revich, 2011; Shaposhnikov et al., 2014).

In recently published studies, excess mortality has also been evaluated separately during other extreme summer heat waves in various parts of Europe: for example in 2006, it was mainly in Western Europe (Fouillet et al., 2008; Monteiro et al., 2013; Knobová et al., 2014); in 2007, mainly in Central and Southeastern Europe (Overcenco, 2010; Páldy and Bobvos, 2010; Opopol et al., 2012; Bogdanović et al., 2013; Corobov et al., 2013; Stanojević et al., 2014); and in Central Europe, most recently in 2011 and 2012 (Páldy and Bobvos, 2012).

The largest increase in mortality during heat episodes is recorded mainly on days with the most uncomfortable temperature conditions (Matzarakis et al., 2011). Special attention is dedicated to situations with an extended duration of heat stress. Despite the capacity of the human organism to tolerate extreme heat stress for short periods of time, periods with longer duration represent a different group of stressors associated with a larger risk of death, as a sequence of consecutive hot days puts a higher strain on the human thermoregulatory system (e.g. Gosling et al., 2009; Kenney et al., 2014).

There was a particularly higher risk of death found in persons within several specific population groups, which have logically become a centre of interest in the corresponding analyses. Proper identification of these groups is decisive for possible public health interventions and their effectiveness (Hajat and Barnard, 2014).

Most European studies confirm that females are usually a more vulnerable group (Kovats and Hajat, 2008), and in Central Europe this situation is quite consistent (e.g. Hutter et al., 2007; Kyselý and Plavcová, 2012; Páldy and Bobvos, 2012). The results of several European research publications have shown somewhat higher long-term sensitivity in females during heat waves when taking into account variations in age structure as well (Matzarakis et al., 2011; Hajat and Barnard, 2014).
From the physiological point of view, the organism in old age can not fully compensate meteorological effects in a natural way due to a multitude of factors (Morabito et al., 2012). Indeed, increases in mortality of the elderly tend to be among the largest in heat episodes (e.g. Basu, 2009; Oudin Åstrom et al., 2011; Yu et al., 2012; Kenney et al., 2014). This can be essential information in the context of population ageing, which is, in both the shortand the long-term, an important current problem in the Slovak population as well (Mládek and Káčerová, 2008). As the elderly are expected to be potentially more susceptible to heat exposure, an aging population is logically more at risk (e.g. Gosling et al., 2009; Kenney et al., 2014). This hypothesis was confirmed in the Czech Republic (Kyselý and Plavcová, 2012), and it could also apply to Slovakia where population ageing shows an exceptionally high degree of similarity to that of the Czech Republic (Káčerová et al., 2012).

People suffering from circulatory system diseases are often found to be at the highest risk in relation to higher air temperatures in biometeorological research (e.g. Basu, 2009; Hajat and Barnard, 2014; Kenney et al., 2014). Slovakia belongs to the set of European countries with high mortality rates from diseases of this group (Baráková, 2009; Helis et al., 2011; Šprocha et al., 2015).

To determine true (net) heat-related mortality, investigators must account for a compensating effect of mortality displacement (also known as harvesting) (Saha et al., 2014). The basic principle of this phenomenon is that an extreme weather event (such as a heat period) mainly affects people with poor health, who would die in a very short period of time anyway, regardless of the weather (Gosling et al., 2014). In other words, a negative weather event kills some of those people who would have died soon under normal weather conditions. This means that an extreme weather event in fact does not cause true excess mortality, but only a short-term shift in deaths among terminally-ill people (Martiello and Giacchi, 2010), and a period of elevated mortality is followed by a compensatory period with a deficit of deaths.

As already suggested, the issue of hot weather influences on human mortality has been frequently analysed over the last years, and in the European context this is valid mainly for the most developed Western European countries. Although research in this field has improved lately, it is still somewhat less common in the wider region of Central European countries. Several contributions have focused on the population of the Czech Republic (e.g. Kyselý, 2004; Kyselý and Huth, 2004; Kyselý and Křriž, 2008; Kyselý and Plavcová, 2012; Knobová et al., 2014), as well as Austria (Hutter et al., 2007; Muthers et al., 2010a,b; Matzarakis et al., 2011), Switzerland (Grize et al., 2005), Poland (Kuchcik and Degórski, 2009), Hungary (Páldy et al., 2005; Páldy and Bobvos, 2010, 2012), Croatia (Zaninović and Matzarakis, 2014), Serbia (Bogdanović et al., 2013; Stanovejić et al., 2014), and Moldova (Overcenco, 2010; Opopol et al., 2012; Corobov et al., 2013). In several cases, and this is also valid in global terms, most of the studies were aimed specifically at populations of larger cities or metropolitan areas where a higher risk of death can be generally expected due to a higher sensitivity of the population as a consequence of climate (urban heat island, higher air pollution, etc.) and socioeconomic (e.g. certain lifestyle) factors. Therefore, studies focused on large areas and entire countries are still rare in Central Europe. 
In several publications (e.g. Gosling et al., 2009; Plavcová and Kyselý, 2014) there are discussions that some of the analyses in biometeorological research cover a relatively short time period (most often individual heat waves and individual hot summers), or the research is commonly established on relatively small population samples from single or only a small number of hospitals (this is how the latest research has been done in Slovakia as well: see Štvrtinová et al., 1990; Čabajová et al, 1999; Čabajová, 2005). One advantage of this group of investigations, for example, is a higher quality-determined cause of death of a person based on a medical or autopsy record, compared to cases when the official cause of death is determined only on the basis of the examining doctor's report. Nevertheless, the collection of clinical data from larger territories with larger population samples is usually complicated, and it is also necessary to consider that people do not always die in hospitals or undergo autopsies.

\section{Material and methods}

\subsection{Meteorological data}

Data on daily mean air temperature and daily mean water vapour pressure (the latter, for discussion purposes only) was used. Daily means are calculated from actual temperatures observed at 7, 14, $21 \mathrm{hrs}$ local time.

Data series from 23 climatological stations (Fig. 1) over the period 1996-2012 were provided by the Slovak Hydrometeorological Institute. The stations represent the whole territory and include the various climatic regions of Slovakia. Likewise, the stations represent various altitudes except for the mountain and high mountain ranges, in which permanent settlements are not located or where there is a negligible number of inhabitants. In the end, the stations represent practically all of the most densely populated areas (Fig. 1) and, at the same time, take into account the distribution of the Slovak population in terms of the absolute number of inhabitants in the studied time period.

\subsection{Identification of heat events}

According to Robinson's (2001) general definition, a heat wave is an extended period of unusually high atmosphericrelated heat stress, which causes temporary modifications in lifestyle and which may have adverse health consequences for the affected population. Based on this definition, the author specifically mentions that heat waves can not be evaluated without considering their impacts on human society. Robinson further states that a definition of heat wave must include the combined effect of weather elements and effects which affect the thermal sensation of the human body. Also, defined thresholds have to consider the effects of both daytime high and night-time low air temperatures, respecting the variability of climatic conditions in the given area. The effect of duration also needs to be included (Robinson, 2001), which also results from another general definition by Gosling et al. (2014), according to which a heat wave is a period of extreme high temperature that lasts several days. Due to the fact that not all of the above-mentioned criteria were respected precisely in our analysis, we prefer more simple terms rather than "heat wave" in our terminology.

Furthermore, a specific universal definition to determine a heat wave has not been generally accepted in the scientific literature (e.g. Robinson, 2001; Kuchcik, 2006; Gosling et al., 2009). Likewise, heat episodes still do not have an official definition in Slovak meteorological and climatological practice nor in public health, and they are not monitored in Slovakia to create an early warning system (Koppová, 2011). In our analysis, we applied the quantile approach (cf. Gosling et al., 2009) to identify "heat days" as the days when the daily mean air temperature anomaly from normal exceeded the value of the $90^{\text {th }}$ percentile of its empirical distribution in the summer months (June, July, August) over the full period of interest (1996-2012). To evaluate the effects of the most extreme temperatures, we also similarly determined the days with anomalies above the $95^{\text {th }}$ percentile value - we define these as "strong heat days".

An advantage of using anomalies from normal is that it effectively removes the mean temperature variation between stations (effects of various elevations, specific locations, etc.). Anomalies were specifically set for each of the stations and consequently an average value representing the entire Slovak territory was calculated. When calculating temperature normals, the annual cycle was smoothed by 7-day centred moving averages. This type of smoothing was chosen from several alternatives as optimal, because it preserves the annual cycle singularities to a suitable degree and simultaneously it smoothes its irregularities (large day-to-day variability). In addition, 7-day moving averages correspond well with the mean duration of a natural synoptic period (Sobíšek, 1993).

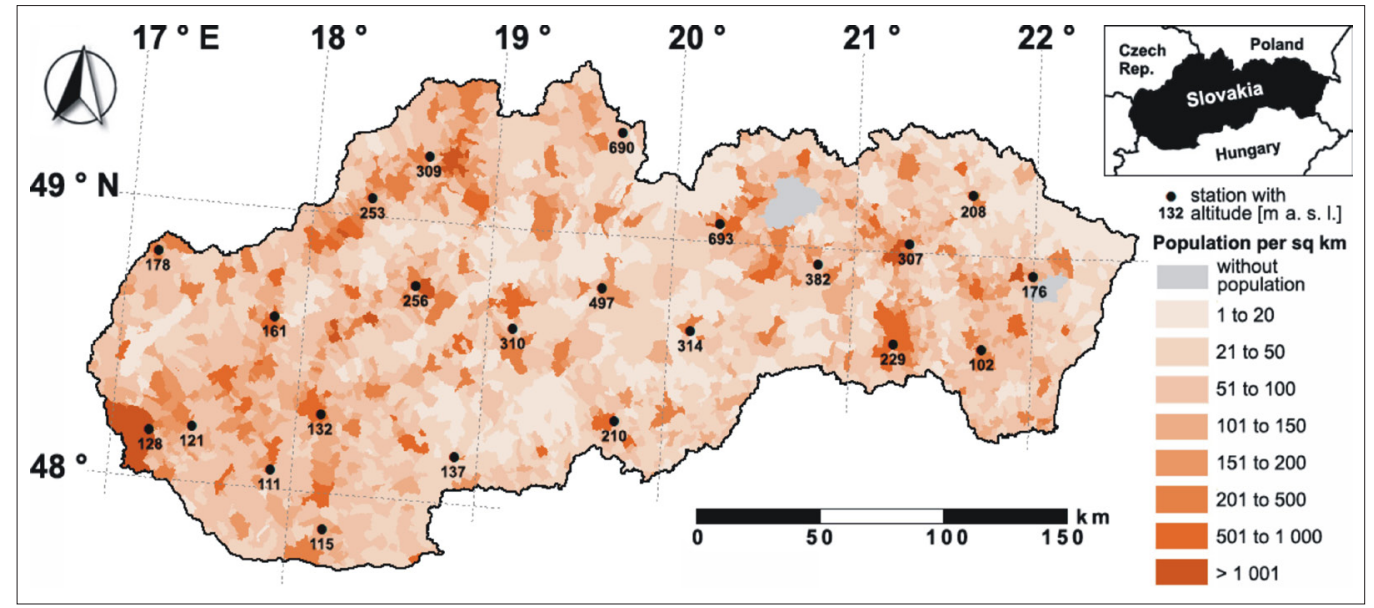

Fig. 1: Location of climate stations and population density in Slovak communes (according to the 2001 Population and Housing Census)

Source: Prepared following Kusendová and Tomášiková (2006) 
We use the term 'heat events' for the compact episodes of heat in this paper. 'Heat events' were classified according to their duration. Our main focus was on the events with duration of two or more "heat days", and we define these situations as multi-day "heat periods", while 'isolated heat day' refers to a one-day heat event. According to Kyselý and Plavcová (2012), hot spells of at least 2 days result in a much higher response in mortality than isolated hot days. At least two-day duration is also recommended by Robinson (2001), and last but not least, such a selection is more suitable with respect to duration criterion as specified in general definitions of heat episodes. Multiple heat events, separated by only one non-heat day with a slight drop of temperature anomaly below the threshold, were evaluated together as a single heat period. In our terminology please note that 'strong heat events' relate to 'strong heat days', but their further classification based on duration was not used.

There are several reasons why we prefer applying the simple daily mean air temperature variable as the mortality predictor rather than any of the biometeorological indices (de Freitas and Grigorieva, 2015). Based on their analysis, Barnett et al. (2010) recommend the use of simple air temperature characteristics when assessing heat-related mortality due to practical reasons such as their longterm availability, the smaller number of missing data in time series, and good spatial coverage of the studied area. The authors of that study did not find any significant differences between the usage of simple air temperature characteristics and biometeorological indices, and state that the selection of the mortality predictor is much less important than some other tasks. Daily mean temperature is an equivalent alternative, and in the case of an evaluation of heat-related mortality it shows similar results as various biometeorological indices according to other studies as well (Kim et al., 2011; Vaneckova et al., 2011). Urban and Kyselý (2014) also confirmed this finding in Central Europe when evaluating heat effects on cardiovascular mortality in the neighbouring Czech Republic.

\subsection{Mortality data}

A database of deaths for the years 1996-2012 was provided by the Public Health Authority of the Slovak Republic based on datasets of the Statistical Office of the Slovak Republic. Each death record includes the date of death. Based on this information, daily death counts were established. Each record also includes information on the sex and age of the deceased, as well as the cause of death. After reviewing the quality of these data, in addition to total (all-cause) mortality, mortalities of three specific population sub-groups were also analysed: by sex, both males and females; and by age, the elderly aged 70 years and older. Country-wide mortality was evaluated: the whole country population is usually exposed to heat situations, which tend to be spatially extensive events, so they easily impact the entire territory of Slovakia ( 49,000 sq km).

For the purpose of mortality evaluation, we applied the procedure of calculating deviations of death counts from baseline (expected) mortality (cf. Gosling et al., 2009); this procedure is known as indirect standardization. Baseline daily mortality values were calculated based on the methodology used over a longer period of time in the biometeorological research in the Czech Republic (e.g. Kyselý, 2004; Kyselý and Kříž, 2008; Kyselý and Plavcová, 2012; the latest exact procedure is described in detail, for example, in the study by Hanzlíková et al., in press).
Daily baseline mortality $\mathrm{M}_{0}(y, d)$ for year $y$ and day $d$ was calculated as follows:

$$
\mathbf{M}_{0}(y, d)=\mathbf{M}_{0}(d) \times \mathrm{W}(y, d) \times \mathbf{Y}(y)
$$

where $\mathrm{M}_{0}(d)$ denotes the mean annual cycle of mortality in the period of interest determined as the average number of deaths in the given day of the year; $\mathrm{W}(y, d)$ is the correction factor for the weekly cycle of mortality for individual days of the week, defined as the ratio of mean mortality on a given day of the week to the overall mean daily mortality, with the influence of public holidays eliminated; and $\mathrm{Y}(y)$ is the correction factor for year-to-year changes in mortality, defined as the ratio of number of deaths in the given year to the mean annual number of deaths during the analysed period.

The correction factors $\mathrm{W}(y, d)$ and $\mathrm{Y}(y)$ were calculated over the period May-September, outside the season of influenza, influenza-like illnesses and acute respiratory infections, which could significantly affect mortality. This modification in the selection of time period for calculating correction factors was our only adjustment in the process of mortality data standardization presented in the source publication (cf. Hanzlíková et al., in press), resulting from the unavailability of necessary epidemiological data.

Deviations of observed mortality from baseline (expected) mortality were calculated for each day and summed (absolute characteristics)/averaged (relative characteristics) over the relevant time periods of heat events. Immediate direct effects on mortality (without lags) were considered. The 95\% confidence interval was selected to evaluate the statistical significance of deviations. Confidence intervals of deviations were calculated based on the procedure suggested by Morris and Gardner (1988) for a Poisson-distributed variable. This method is suitable for the approximation of larger statistical samples with more than 20 observed cases.

This complete methodological approach of calculating baseline mortality and of following the establishment of mortality deviations is appropriate when analysing longer time series, as such an approach takes into account both longterm (reflecting especially overall socioeconomic changes) and short-term changes in mortality (Gosling et al., 2009; Hanzlíková et al., in press).

\subsection{Target population}

In terms of the number of inhabitants, Slovakia represents a mid-sized European population. Between 1996 and 2012, the mid-year population on July $1^{\text {st }}$ fluctuated around the value of 5.4 million (Statistical Office of the Slovak Republic, 2014). In the summer months of 1996-2012, the average daily total number of deaths was 137.2 , of which 64.5 (47.0\% of total mortality) of the deceased were females, 72.7 $(53.0 \%)$ males, and $82.5(60.1 \%)$ the elderly aged 70 years and older. A more detailed picture of the corresponding mortality trends in Slovakia in the long term can be found in the recent study by Šprocha et al. (2015).

\section{Results}

\subsection{Basic evaluation of overall (long-term) impacts of the heat events on mortality}

Daily mean air temperature anomaly, necessary for classification of situations as heat days (strong heat days), was $3.90(4.97){ }^{\circ} \mathrm{C}$. The average anomaly during heat events (strong heat events) was $5.23(6.01)^{\circ} \mathrm{C}$. We would like to emphasise that all of the presented temperature anomalies 
represent spatial averages calculated from a larger number of stations (see Fig. 1 and Section 3.2: Identification of heat events, above).

In the 17-year period under investigation, more than 2,160 excess deaths in total were recorded in Slovakia during the identified heat events (157 days in total). This value represents a total relative increase of 9.9\% (95\% CI: $8.5 \%$ to $11.3 \%$ ) compared to expected mortality. The mortality increase was more pronounced among females (11.4\%; 95\% CI: $9.4 \%$ to $13.5 \%$ ) in comparison with males $(8.5 \%$; $95 \%$ CI: $6.6 \%$ to $10.5 \%)$. An excess mortality of $11.3 \%$ (95\% CI: $9.5 \%$ to $13.2 \%$ ) was found in the elderly at the age of 70 and older. The approximate proportion of excess deaths in total excess mortality was $55 \%$ for women and $69 \%$ for the elderly.

If we focus only on strong heat events (79 days in total), increases in relative deviations of mortality were even higher by 3 to $5 \%$. In total mortality, it was $13.9 \%$ (95\% CI: $11.9 \%$ to $15.9 \%$ ), i.e. more than 1,530 deaths. This means that approximately $70 \%$ of all heat events-induced excess deaths were recorded during strong heat events. In individual population groups, mortality increased by $13.3 \%$ (95\% CI: $10.6 \%$ to $16.1 \%$ ) for males, by $14.5 \%$ (95\% CI: $11.6 \%$ to $17.4 \%$ ) for females, and by $16.2 \%$ (95\% CI: $13.6 \%$ to $18.8 \%$ ) for the elderly. The approximate proportion of excess deaths in total excess mortality during strong heat events was $50 \%$ for women and $71 \%$ for the elderly.

\subsection{Mortality during the major heat events}

An overview of most severe individual multi-day heat periods and their impacts on mortality is shown in Table 1. Annual statistics of summer heat events and corresponding mortality are presented in Figure 2. Selected summers are separately shown in Figure 3.

The longest total duration of heat events in the analysed period occurred in 2012. During 21 days of summer heat events in this year, a $13.0 \%$ (95\% CI: $9.2 \%$ to $17.0 \%$ ) increase in total mortality was recorded, accounting for more than 370 excess deaths. Within individual 2012 heat periods, a large part of the excess deaths was caused by the period that began on the very last day of June. In relation to heat events in the first half of the summer of 2012, a remarkable deficit in mortality occurred between the $13^{\text {th }}$ and $23^{\text {rd }}$ of July, which may correspond to a mortality displacement effect. In total mortality, this 11-day reduction was statistically significant (-13.5\%; 95\% CI: $-18.2 \%$ to $-8.7 \%)$ and it compensates for more than 200 deaths from the total of approximately 230 excess deaths recorded during heat events in the first half of summer 2012.
Total mortality during the 2010 summer heat events exceeded the expected value by $13.6 \%$ (95\% CI: $9.2 \%$ to $18.3 \%$ ), i.e. almost 300 excess deaths during the 15 days of heat events. The heat peaked in an extreme one-week heat period in mid-July with a highly significant increase in mortality. Shortly after this period, another short period with lower impacts on mortality occurred, followed by a significant $-5.1 \%$ (95\% CI: $-8.9 \%$ to $-1.0 \%$ ) deficit between the $24^{\text {th }}$ July and $9^{\text {th }}$ August, which is equivalent to more than 120 displaced deaths. Even though a higher sensitivity of females was characteristic both in general, as well as during the majority of individual heat events, a much higher excess mortality of males was recorded for the most severe heat period in July 2010. This finding generally applies to all 2010 heat events as well: an excess of $15.0 \%$ (95\% CI: $9.0 \%$ to $21.7 \%$ ) was found in the case of men, while for women: $12.2 \%$ (95\% CI: $5.8 \%$ to $18.7 \%$ ).

During the summer heat events of 2007 (13 days), a total mortality increase of $12.4 \%$ (95\% CI: $7.6 \%$ to $17.3 \%$ ) was recorded in Slovakia. In the dominant extreme heat period in July, the most fatal day (19 ${ }^{\text {th }}$ July 2007) of the entire analysed period was recorded, with both the highest absolute (almost 65 excess deaths) and relative (44.4\%; $95 \%$ CI: $25.4 \%$ to $65.4 \%$ ) deviation of total mortality. A large significant increase during this 8-day heat period, accounting for around 220 excess deaths, was followed by an extended period of reduced mortality. Between the $25^{\text {th }}$ July and $17^{\text {th }}$ August 2007, total mortality was $-3.8 \%$ (95\% CI: $-7.1 \%$ to $-0.4 \%$ ) below the baseline, meaning a deficit of around 125 deaths. The next compact period of time with mortality well below the expected level was recorded in the first half of September 2007, when during the first thirteen days of the month the deviation of mortality reached negative values in all but two days (not shown). The deficit was statistically significant as well $(-4.9 \%$; $95 \%$ CI: $-9.4 \%$ to $-0.3 \%)$, accounting for approximately 90 displaced deaths.

During the very hot summer of 2003, a long total duration (17 days) of heat events was recorded. With the exception of the period at the beginning of June, however, these were just isolated heat days or 2-day heat periods. Altogether, 2003 summer heat events caused only a moderate increase in total mortality by $6.0 \%$ (95\% CI: $1.8 \%$ to $10.3 \%$ ) compared to the expectation. Other remarkable individual heat periods (Tab. 1) and summers (Fig. 2), respectively, with significant impacts on mortality, were recorded in 1998, 2000 and 2006. In addition to the situations in 2010 and 2012 described above, among the last three analysed years, 2011 summer heat events (12 days in total) also resulted in a significant increase (11.1\%; $95 \%$ CI: $5.8 \%$ to $16.3 \%)$ in total mortality.

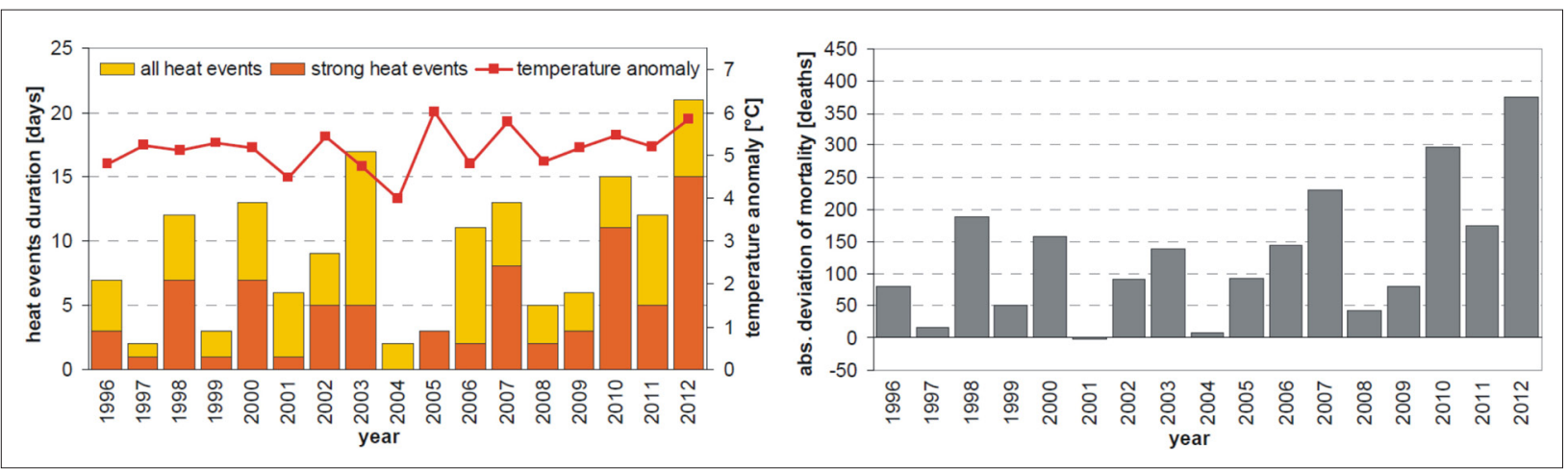

Fig. 2: Duration of heat events, average value of daily mean temperature anomaly (left chart) and total mortality deviations (right chart) during 1996-2012 summer heat events in Slovakia. 


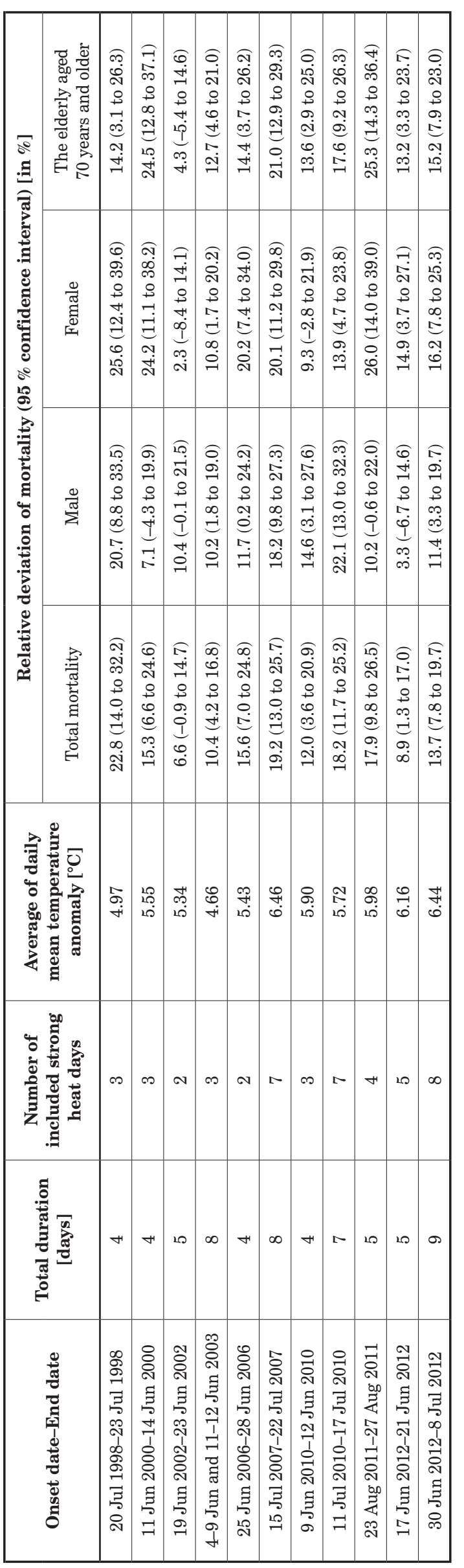

\subsection{Mortality during isolated heat days and multi-day heat periods}

Twenty-one isolated heat days (with average daily mean temperature anomaly of $4.56{ }^{\circ} \mathrm{C}$ ) and forty multi-day heat periods $\left(5.33^{\circ} \mathrm{C}\right)$ were recorded. The increase in mortality was much higher during the multi-day periods, while it was even statistically not significant for the isolated heat days (Tab. 2). From the total amount of 2,160 excess deaths, more than $96 \%$ were recorded during multi-day heat periods.

\subsection{Mortality regime related to multi-day heat periods}

In the period 1996-2012, 2.35 multi-day heat periods occurred per year on average, with average duration of 3.4 days. Since the multi-day periods were responsible for the vast majority of total excess deaths, we analysed a typical regime of mortality in the time sequence of 5 days (day -5 ) before the onset of a heat period, up to 30 days (day 30 ) after the onset (Fig. 4).

On average, there was a slight, but only in a few cases statistically significant, increase in mortality prior to the onset of a heat period on almost all days of the 5-day pre-sequence. At the beginning of a heat period (day 0), mortality rose significantly and remained markedly high for several following days. Soon afterwards, a decrease to below-baseline level was observed and negative deviations of mortality persist until the end of the whole 30-day sequence after the onset of a heat period. This indicates the effect of mortality displacement.

Mortality effects are in line with the results presented earlier, being more pronounced in females and the elderly. With a focus on the following most critical days, male mortality was more pronounced on the initial day of a heat period (day 0 ). The highest relative deviation of mortality from baseline was reached for the whole population and both gender groups one day (day 1 ) and for the elderly two days (day 2) after the onset of a period. Another interesting finding is that deviations of mortality stayed consecutively positive, on average, for a week (days 0 to 6 ) of a heat period in all population groups, with the exception of males in which mortality was above the baseline for just the first five days (days 0 to 4 ) of a period.

\section{Discussion}

\subsection{Overall long-term heat impacts on mortality}

Despite differences in methods and the time periods used, overall increases in mortality during heat events in Slovakia are in accordance with the results of studies from neighbouring countries analyzing mortality over longer time periods (e.g. Kyselý, 2004; Hutter et al., 2007; Kyselý and Kříž, 2008; Matzarakis et al., 2011; Stanojević et al., 2014). The highest relative increases during the individual heat periods exceeded $20 \%$, which is also similar to other Central European studies (Kyselý, 2004; Páldy et al., 2005).

\subsection{Summer heat in 2003}

Although the 2003 May-August season was extremely hot in Slovakia (Faško et al., 2003) and the corresponding summer was, in terms of average temperature, the hottest in the history of meteorological observations at several stations across Slovakia, the 2003 summer heat events were associated with only a moderate $6 \%$ increase in total mortality. In spite of the diversity of applied methodologies, this value corresponds very well with the results of other studies confirming less dramatic heat impacts of the summer 


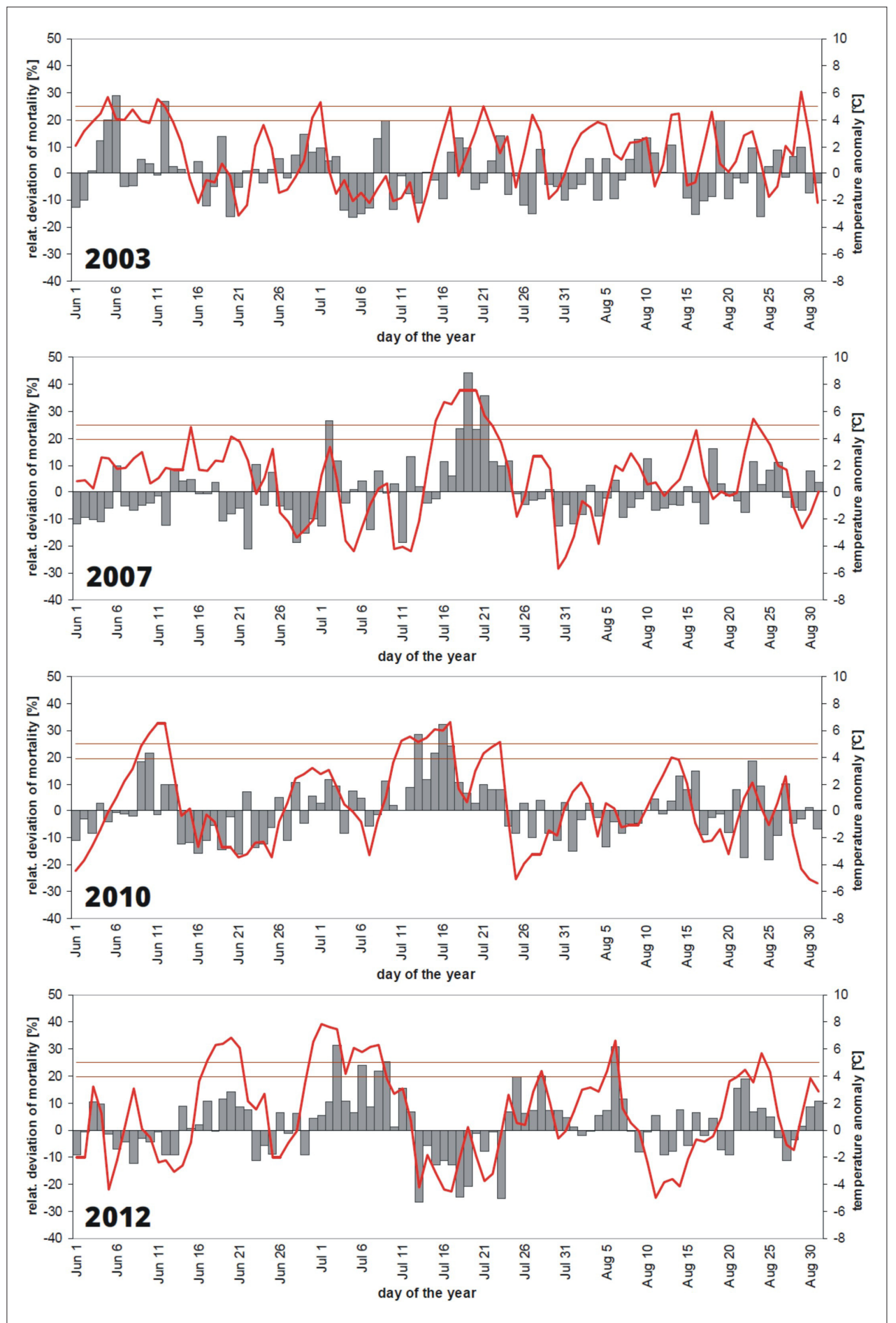

Fig. 3: Temperature conditions (lines) and total mortality (bars) in selected summers in Slovakia. Note: The red curve shows daily mean temperature anomalies; horizontal lines represent the threshold values of daily mean temperature anomaly for the classification of heat and strong heat days, respectively.

\begin{tabular}{|l|c|c|}
\hline & Isolated heat days & Multi-day heat periods \\
\hline Total mortality & $2.8(-0.9$ to 6.5$)$ & $11.0(9.5$ to 12.5$)$ \\
\hline Male & $1.6(-3.4$ to 6.7$)$ & $9.6(7.6$ to 11.7$)$ \\
\hline Female & $4.0(-1.3$ to 9.6$)$ & $12.6(10.4$ to 14.8$)$ \\
\hline The elderly aged 70 years and older & $3.7(-1.0$ to 8.6$)$ & $12.4(10.6$ to 14.5$)$ \\
\hline
\end{tabular}

Tab. 2: Relative deviations of mortality [\%] from baseline during isolated heat days and multi-day heat periods in Slovakia, 1996-2012. Note: Multiple heat events, separated by only one non-heat day with a slight drop of temperature anomaly below the threshold, were classified as a single heat period; values in brackets represent 95\% confidence intervals of deviations. 


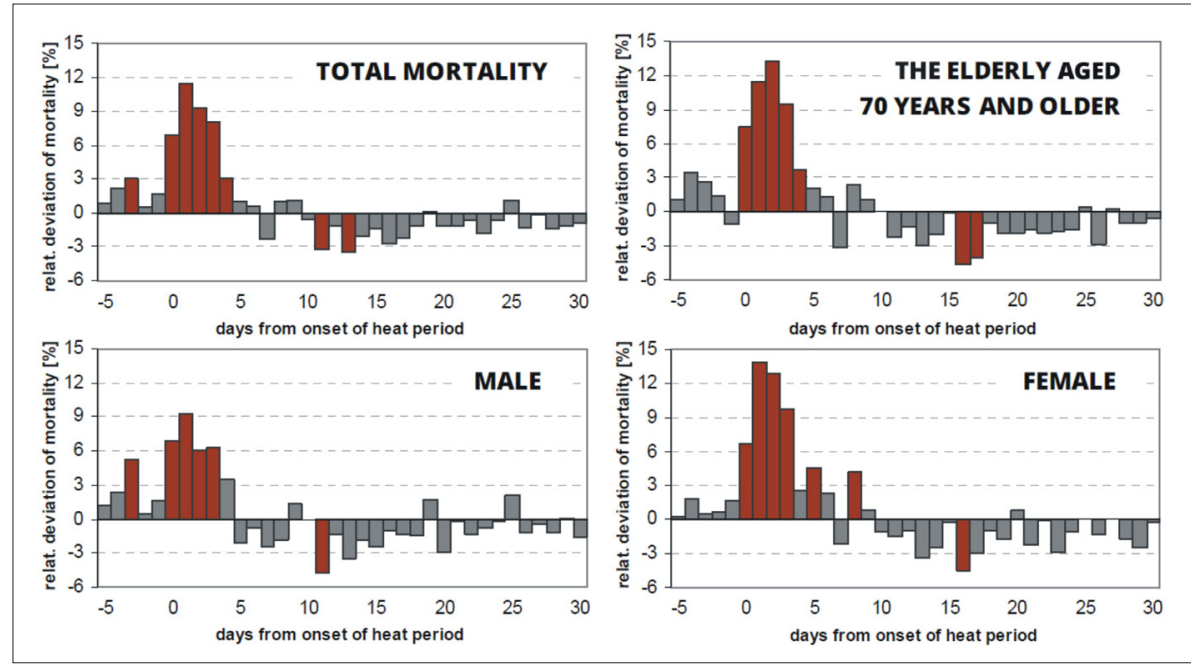

Fig. 4: Mortality regime related to multi-day summer heat periods in Slovakia, 1996-2012. Note: The brown bars indicate statistically significant values at the 95\% level (based on the relevant confidence interval); multiple heat events, separated by only one non-heat day with a slight drop of temperature anomaly below the threshold, were classified as a single heat period.

of 2003 on the mortality of Central European populations. For example, an excess total mortality of $2.9 \%$ during four heat waves was recorded in the Czech Republic (Kyselý and Kř́ž́, 2008). In Prague, the increase during an extended heat peak period between the $2^{\text {nd }}$ and $22^{\text {nd }}$ of August was $3.2 \%$ (Knobová et al., 2014), in Vienna 5\% for the entire summer (Hutter et al., 2007) and in Switzerland 6.9\% for the entire summer (Grize et al., 2005). These values are considerably lower than those for the majority of the Western European countries (cf. Kosatsky, 2005; Robine et al., 2008; GarcíaHerrera et al., 2010), where the heat was much more severe in meteorological terms. During the first half of August, when heat waves and the mortality crisis peaked in the most impacted countries in Western Europe, no remarkable heat period was recorded in Slovakia. At the least, relatively low values of excess mortality in Slovakia could have been attributable to more comfortable humidity conditions (lower values of water vapour pressure) and also to the fact that heat events were distributed evenly throughout the summer (Fig. 3), which likely contributed to a gradual improvement in the physiological and behavioural seasonal acclimatization of the population to the persisting hot weather.

\subsection{Summer heat in 2007}

The extreme heat of 2007 was primarily concentrated in Southeastern Europe and also some parts of Central Europe (Corobov et al., 2013). In Central Hungary, including Budapest, mortality during the hottest days rose by $12 \%$ (Páldy and Bobvos, 2010), which is a comparable value with the results of our analysis (12.4\%). A particularly extreme heat spell occurred in the second half of July 2007. During this episode, mortality increased by $38 \%$ in Belgrade (Bogdanović et al., 2013) and by $32.9 \%$ in Central Hungary (Páldy and Bobvos, 2010), and these values are much higher than in Slovakia (Tab. 1). It is necessary, however, to take into consideration the metropolitan character of Belgrade and Budapest with possibly higher mortality risks. Nevertheless, the severity of this extreme heat period is indisputable for the case of Slovakia, as this was the period during which the highest national temperature on record was observed $\left(40.3^{\circ} \mathrm{C}\right.$ in Hurbanovo on the $20^{\text {th }}$ of July). It was the only severe heat episode in the summer of 2007 and this could play a role in a very high excess mortality recorded during this period.
No significant deficit in mortality, corresponding to mortality displacement, was recorded immediately after the July heat period in Moldova (Corobov et al., 2013), Serbia (Bogdanović et al., 2013), or in Hungary (Páldy and Bobvos, 2010). The authors of the cited Moldavian study, however, noticed markedly negative excess mortality in September 2007 and they stated that this was a reduction related to post-heat mortality displacement. In Slovakia, we observed a moderate, statistically significant mortality deficit in the period of approximately three weeks after the extreme heat period in July (Fig. 3), and a similar situation occurred in the first half of September. These deficits are most likely attributable to the mortality displacement effect. In contrast to the above-mentioned studies, an apparent extended short-term mortality displacement was observed as the result of 2007 heat events in Slovakia.

\subsection{Summer heat in 2010, 2011 and 2012}

Only a small number of European studies have dealt with the influence of the 2010-2012 heat episodes on mortality. In Slovakia, heat events in these summer seasons occurred with higher frequency and their response in mortality was remarkable: each year the relative deviation of total mortality from the baseline exceeded $10 \%$.

The centre of 2010 heat was in the European part of Russia. According to Shaposhnikov et al. (2014), total mortality in Moscow was 90\% above the selected baseline for the 44-day July-August heat wave. In the same location, total mortality in July and August 2010 increased by $59.6 \%$ compared to 2009 . A similar comparison for the 43 administrative regions of European Russia, including Moscow, showed an excess mortality of $19.5 \%$ and $32.6 \%$ in July and August of 2010, respectively (Revich, 2011). It is clear that the excess during the 2010 heat episodes was much higher in Russia than in Central Europe. In Frankfurt, the total mortality increase during the 2010 summer heat waves was $22.7 \%$ (Heudorf and Schade, 2014), and the increase during heat events identified in Slovakia (13.6\%) was not negligible either. We believe that this high value may have been positively influenced by air humidity, as 2010 was by far the most extreme year in terms of record-breaking precipitation in Slovakia. Precipitation totals exceeded long-term averages practically in each month. They were 
especially extreme in April, May and June, and there were also large regional floods at the turn of May and June (Pecho et al., 2010); but rainfall was also frequent in July and August. Therefore, the pre-existing high soil humidity led to a higher evaporation and water vapour pressure (the country-wide spatial average was $20.65 \mathrm{hPa}$ during the 15 days of heat events). Consequently, people were exposed to a greater temperature-humidity discomfort on the hottest days, and such conditions might have caused a more negative response in mortality.

The only European publication analysing the effects of 2011 and 2012 heat on mortality that we are aware of is a Hungarian study by Páldy and Bobvos (2012). During the relevant hot days in the summer of 2011, total mortality in Hungary increased by approximately $13 \%$, which roughly corresponds with the $11.1 \%$ increase observed in Slovakia. Similar results for the next year show that the 2012 summer heat spells had larger impacts on mortality in Hungary. Total mortality increased by approximately $20 \%$ in comparison with $13 \%$ during the heat events identified in Slovakia. The difference appears to be quite prominent. It is most likely the consequence of temperature conditions as heat was more intense in the regions southward from Slovakia (Hungary, Serbia, Romania, etc.).

A further difference between the results presented in our study and the results of the Hungarian study is the observation of mortality displacement in 2012. While a marked deficit in mortality was recorded in Slovakia after the major June-July heat period, this phenomenon was not observed in Hungary (Páldy and Bobvos, 2012).

It was the period at the turn of June and July 2012 which was the most remarkable individual 2010-2012 summer heat event from a meteorological point of view. Despite the fact that mortality increased significantly during this heat period, it did not reach the high value of a comparable heat period in July 2007. A partial reason for that could be an earlier heat period in June 2012, which could have influenced mortality in the following period due to mortality displacement and positive seasonal acclimatization to heat.

\subsection{Mortality displacement}

We have shown that short-term mortality displacement was well expressed after the heat periods in Slovakia (Fig. 4), particularly the most extreme individual ones (Fig. 3). There is no general consensus about the length of the period over which mortality displacement can be expected (Toulemon and Barbieri, 2008; Saha et al., 2014). This was the main reason why we have not defined the exact time frame during which the effect was evaluated. In Slovakia, the pattern of mortality displacement also varied in individual situations. Reduction in mortality was in some cases rapid, occurring immediately after the period of anomalously hot weather, but in other cases daily mortality deficits were smaller and remained as such for a longer period of time.

The role of mortality displacement is probably less important in situations where deaths associated with heat stress do not occur predominantly among terminally ill people (very old, suffering from chronic diseases, etc.). This is typical during most extreme heat episodes when a larger proportion of deaths might occur for otherwise immune individuals (e.g. García-Herrera et al., 2010; Hajat and Barnard, 2014; Saha et al., 2014). As has been shown (Figs. 3 and 4), displaced mortality accounted for a large part of excess mortality during heat periods in Slovakia, and this was also the case for the most severe individual heat events.
This finding is in accordance with studies focusing on the populations of the Czech Republic (Kyselý, 2004; Kyselý and Plavcová, 2012) and Budapest (Gosling et al., 2007), i.e. other populations from transforming Central European countries.

With regard to displacement, there is an assumption of a true favourable impact of a lower temperature range on mortality after a period of very hot weather. On average, no unusually negative values of daily mean temperature anomaly over the days following heat periods were found (not shown). Thus, mortality displacement seemed to be a dominant factor for the extent of post-heat mortality reduction in Slovakia.

\subsection{Heat impacts on selected population groups}

For the Slovak population, we can confirm that the elderly are among the most sensitive population groups during heat episodes. Generally, higher risk of death was identified in females compared to males in Slovakia, although in some cases, for example, during the summer heat events of 2010 , male mortality was more pronounced. The risk of death in otherwise less-sensitive males increased during the strong heat events.

Some interesting aspects of the mortality regime of the selected population groups were observed in Slovakia during the multi-day heat periods (Fig. 4). Despite the fact that males are generally less sensitive, their mortality was better expressed on the very first day of a heat period; this suggests that men are more sensitive to the onset of extremely high temperatures. On the other hand, the most negative response in male mortality vanished in a shorter period of time in comparison to females and the elderly, in the case of which the most fatal impacts of hot weather persisted for a few more days.

\subsection{Mortality related to multi-day heat periods}

Multi-day heat periods were accompanied by a much higher negative response in mortality in the Slovak population, and the longest individual periods were usually the most severe events from this point of view (Tab. 1). Generally, exceptions to this situation can be caused by several factors. The number of days with particularly strong heat stress within a multi-day sequence seems to play an important role. Within-season acclimatization to high temperatures may also have an effect, i.e. negative impacts decrease in each subsequent hot period of a season due to improved physiological short-term adaptation to heat, positive changes in population behaviours during heat episodes, and possibly also due to mortality displacement (e.g. Basu and Samet, 2002; Kyselý and Plavcová, 2012). This hypothesis partially explains the different impacts of the extreme July 2007 and June-July 2012 heat periods on mortality in Slovakia. Both of these periods were similar in terms of duration, the number of included strong heat days, or mean temperature anomalies, while the 2012 period was characterized by a higher humidity discomfort (higher average values of water vapour pressure). The observed impacts during the 2012 period, however, were markedly lower (although still fairly negative).

In relation to the multi-day heat periods, it was interesting to note that there was already a slight increase in mortality in the days before their onset (Fig. 4). Five to two days before onset, mean temperature anomaly ranged from -0.28 to $0.67{ }^{\circ} \mathrm{C}$, and it was even not considerably different from its long-term summer value in non-heat days $\left(-0.51^{\circ} \mathrm{C}\right)$. 
This means that temperature conditions in the days before the onset of a heat period did not appear to have a crucial effect on elevated mortality on these days. Moreover, one day before the onset of a period, mean temperature anomaly apparently increased to $2.64{ }^{\circ} \mathrm{C}$; however, the deviation of mortality on that day did not increase greatly and it even dropped into negative values for the elderly. Larger anomalies from the usual values in the days before the beginning of a heat period were not recorded for the water vapour pressure either. Therefore, one could discuss whether mortality was influenced by other meteorological factors besides temperature and humidity, or whether it was true pre-heat excess mortality among the most sensitive humans, perhaps associated explicitly with the weather change (i.e., the onset of warm advection).

\subsection{Limitations}

When assessing mortality, immediate direct effects of heat were considered, i.e. without possible lags in mortality. The strongest correlation of extreme high temperatures and elevated mortality is usually observed with lags ranging from 0 to 3 days (e.g. Basu and Samet, 2002; Gosling et al., 2009; Hajat and Kosatky, 2010; Martiello and Giacchi, 2010). According to some of these authors, the analysis of mortality lags should be a compulsory part of heat-related mortality assessment. Hence, not taking the mortality lags into account could be considered as a certain limitation of our study.

Our analysis also does not include the possible impact of air pollution, which can play a significant role in heat-related mortality (e.g. Basu, 2009; Analitis et al., 2014; Hajat and Barnard, 2014).

This study presents the first results of the 'high temperatures-mortality' investigation in Slovakia. We have attempted to cover a number of aspects in this relationship, but due to the complexity of the issue, of course, there is room to assess more of them in the future. In addition to the alreadymentioned factors, others include, for example, determining temperature thresholds at which mortality begins to increase, a more accurate assessment of mortality displacement, etc.

\subsection{Potential target population groups based on cause of death}

Our original intention was to analyse mortality during heat events by also taking into account causes of death, specifically focusing on mortality from circulatory system diseases (CSD). Following a detailed study of the relevant literature, we eventually decided to omit CSD (and any other cause-specific) mortality from our analysis. The rationale for this decision is that there is a long-term, unreliable determination (miscoding) of causes in death certificates in Slovakia, with a high rate of errors, which leads to an incorrect statistical classification of death causes following the International Classification of Diseases (ICD) subgroups and chapters (Baráková, 2011). Despite some gradual improvement, $10 \%$ of randomly selected causes of 2010 deaths, and $12 \%$ of all officially determined causes of 2011 deaths were incorrectly classified into a different ICD chapter; it is equivalent to 5,400 and 6,200 deaths, respectively, for the entire population (Baráková et al., 2012, 2013). It is obvious that a high number of errors in the source data would undoubtedly lead to a considerable distortion in the obtained results. As a consequence, causespecific mortality analysis seems highly problematic in Slovakia at this time.

\section{Conclusions}

Our study, the first of its kind focusing on the Slovak population, presents a basic insight into the issue of heat impacts on mortality of the population, both overall (longterm) as well as during the major individual events.

The effects of heat events on human mortality in Slovakia fit well into the Central European context. Compared to expected values, the overall mortality of the Slovak population apparently increased during the summer heat events in the period 1996-2012. In this period, there were several extremely hot episodes in Slovakia with mortality very significantly above the baseline; especially remarkable were the summer heat events of 2007, 2010 and 2012. A higher risk of death was found in females compared to males, and in the elderly. Multi-day heat periods had significantly larger negative impacts, and they were also characterized by differences in the mortality regimes within the examined individual population groups. Short-term mortality displacement after the end of heat periods was well expressed, and it seemed to represent a large portion of heatinduced excess deaths.

In any case, the results clearly show that heat events cause non-negligible negative responses in the mortality of the Slovak population. For this simple reason alone is it highly desirable to restart biometeorological research in the country. In addition to heat, this would be also appropriate for other weather effects on population health. In the European context, research in this area may be particularly important in transition countries (such as Slovakia), which have still not reached the level of actions as in some of the most developed countries, where successful efforts to minimize the negative effects of heat (and weather in general) on their populations have already been made (e.g. Pascal et al., 2006; Fouillet et al., 2008; Lowe et al., 2011; Bittner et al., 2013). These results could therefore be particularly useful for future public health interventions, the implementation of which is below an adequate level in Slovakia.

Even after reaching a satisfactory state of overall social adaptability, however, unprecedented extreme heat episodes will still be associated with very large negative effects and excess mortality, even in the developed countries, and their probability is expected to rise in a changing climate (Kyselý and Plavcová, 2012). Therefore, assessments of the 'high temperature-human mortality' relationship remain of high importance worldwide, and it is extremely important in Slovakia which is positioned at the beginning of new research in the area of human biometeorology.

\section{Acknowledgement}

This publication is the result of the project implementation: Comenius University in Bratislava Science Park, supported by the Research and Development Operational Programme funded by the ERDF. Grant number: ITMS 26240220086.

\section{References:}

ANALITIS, A., MICHELOZZI, P., D'IPPOLITI, D., DE'DONATO, F., MENNE, B., MATTHIES, F., ATKINSON, R. W., IŃIGUEZ, C., BASAGAŃA, X., SCHNEIDER, A., LEFRANC, A., PÁLDY, A., BISANTI, L., KATSOUYANNI, K. (2014): Effects of heat waves on mortality: effect modification and confounding by air pollutants. Epidemiology, 25(1): 15-22. 
BARÁKOVÁ, A. (2009): Epidemiologická situácia v SR choroby obehovej sústavy a ich rizikové faktory. Via Practica, 6(1): 17-21.

BARÁKOVÁ, A. (2011): Kvalita listov o prehliadke mŕtveho: Súčasný stav, nové možnosti. Medical Practice, 6(7): 18-19.

BARÁKOVÁ, A., DIBA, S., HLAVA, P. (2012): Štruktúra príčin smrti v SR je skreslená. Cardiology Letters, 21(S1): 9S

BARÁKOVÁ, A., SAFAEI DIBA, C., PEDEROVÁ, E. (2013): Zmeny $\mathrm{v}$ úmrtiach na choroby obehovej sústavy po kompletnej revízii úmrtí za rok 2011. Cardiology Letters, 22(S2): 9S.

BARNETT, A. G., SONG, T., CLEMENTS, A. C. A. (2010): What measure of temperature is the best predictor of mortality? Environmental Research, 110(6): 604-611.

BASU, R. (2009): High ambient temperature and mortality: a review of epidemiologic studies from 2001 to 2008 . Environmental Health, 8(1): 40-52.

BASU, R., SAMET, J. M. (2002): Relation between elevated ambient temperature and mortality: a review of the epidemiologic evidence. Epidemiologic Reviews, 24(2): 190-202.

BITTNER, M.-I., MATTHIES, E. F., DALBOKOVA, D., MENNE, B. (2013): Are European countries prepared for the next big heat-wave? The European Journal of Public Health, 24(4): 615-619.

BOGDANOVIĆ, D. C., MILOŠEVIĆ, Z. G., LAZAREVIĆ, K. K., DOLIĆANIN， Z.Ć., RANDELOVIĆ D. M. BOGDANOVIĆ, S. D. (2013): The impact of the July 2007 heat wave on daily mortality in Belgrade, Serbia. Central European Journal of Public Health, 21(3): 140-145.

CHANGNON, S. A., KUNKEL, K. E., REINKE, B. C. (1996): Impacts and responses to the 1995 heat wave: A call to action. Bulletin of the American Meteorological Society, 77(7): 1497-1506.

COROBOV, R., SHERIDAN, R., OPOPOL, N., EBI, K. (2013): Heat-related mortality in Moldova: the summer of 2007. International Journal of Climatology, 33(11): 2551-2560.

ČABAJOVÁ, Z. (2005): Vplyv počasia na kardiovaskulárny systém. Kardiológia pre prax, 3(2): 108-113.

ČABAJOVÁ, Z., SNOPKOVÁ, Z., TRAUBNER, P., REPISKÁ, V. (1999): Vplyv počasia na výskyt náhlych cievnych mozgových príhod. Bratislavské lekárske listy, 100(5): 267-270.

DE BONO, A., PEDUZZI, P., KLUSER, S., GIULIANI, G. (2004): Impacts of summer 2003 heat wave in Europe. United Nations Environment Programme, Environment Alert Bulletin, 2: 1-4.

DE FREITAS, C. R., GRIGORIEVA, E. A. (2015): A comprehensive catalogue and classification of human thermal climate indices. International Journal of Biometeorology, 59(1): 109-120.

FAŠKO, P., LAPIN, M., SEKÁČOVÁ, Z., ŠŤASTNÝ, P. (2003): Extraordinary climatic anomaly in 2003. Meteorologický časopis, 6(3): 3-7.

FAŠKO, P., ŠŤASTNÝ, P., ŠVEC, M., KAJABA, P., BOCHNÍČEK, O. (2013): Upward trends in time series of basic characteristics of air temperature at selected meteorological stations in Slovakia. Paper presented at the $13^{\text {th }}$ EMS Annual Meeting \& $11^{\text {th }}$ European Conference on Applications of Meteorology (ECAM), Reading (United Kingdom), 9.-13.9.2013. [online]. [cit. 28.08.2015] Available at http://meetingorganizer. copernicus.org/EMS2013/poster/13144

FOUILLET, A., REY, G., LAURENT, F., PAVILLON, G., BELLEC, S., GUIHENNEUC-JOUYAUX, C., CLAVEL, J., JOUGLA, E., HÉMON, D. (2006): Excess mortality related to the August 2003 heat wave in France. International Archives of Occupational and Environmental Health, 80(1): 16-24.

FOUILLET, A., REY, G., WAGNER, V., LAAIDI, K., EMPEREUR-BISSONET, P., LE TERTRE, A., FRAYSSINET, P., BESSEMOULIN, P., LAURENT, F., DE CROUY-CHANEL, P., JOUGLA, E., HÉMON, D. (2008): Has the impact of heat waves on mortality changed in France since the European heat wave of summer 2003? A study of the 2006 heat wave. International Journal of Epidemiology, 37(2): 309-317.

GARCÍA-HERRERA， R., DÍAZ， J., TRIGO， R. M., LUTERBACHER, J., FISCHER, E. M. (2010): A review of the European summer heat wave of 2003. Critical Reviews in Environmental Science and Technology, 40(4): 267-306.

GOSLING, S. N., BRYCE, E. K., DIXON, P. G., GABRIEL, K. M. A., GOSLING, E. Y., HANES, J. M., HONDULA, D. M., LIANG, L., BUSTOS MAC LEAN, P. A., MUTHERS, S., TAVARES NASCIMENTO, S., PETRALLI, M., VANOS, J. K., WANKA, E. R. (2014): A glossary for biometeorology. International Journal of Biometeorology, 58(2): 277-308.

GOSLING, S. N., LOWE， J.A., McGREGOR, G. R., PELLING, M., MALAMUD, B. D. (2009): Associations between elevated atmospheric temperature and human mortality: a critical review of the literature. Climatic Change, 92(3-4): 299-341.

GOSLING, S. N., McGREGOR, G. R., PÁLDY. A. (2007): Climate change and heat-related mortality in six cities Part 1: model construction and validation. International Journal of Biometeorology, 51(6): 525-540.

GRIZE, L., HUSS, A., THOMMEN, O., SCHINDLER, C., BRAUN-FAHRLÄNDER, C. (2005): Heat wave 2003 and mortality in Switzerland. Schweizerische Medizinische Wochenschrift, 135(13-14): 200-205.

HAJAT, S., KOSATKY, T. (2010): Heat-related mortality: a review and exploration of heterogeneity. Journal of Epidemiology and Community Health, 64(9): 753-760.

HAJAT, S., BARNARD, L. T. (2014): Heat-related and cold-related mortality and morbidity. In: Butler, C. D. [ed.]: Climate Change and Global Health (pp. 21-37). Wallingford, CABI.

HANZLÍKOVÁ, H., PLAVCOVÁ, E., KYNČL, J., KŘǏŽ, B., KYSELÝ, J. (in press): Contrasting patterns of hot spell effects on morbidity and mortality for cardiovascular diseases in the Czech Republic, 1994-2009. International Journal of Biometeorology.

HELIS, E., AUGUSTINCIC, L., STENIER, S., CHEN, L., TURTON, P., FODOR, J.G. (2011): Time trends in cardiovascular and all-cause mortality in the 'old' and 'new' European Union countries. European Journal of Cardiovascular Prevention \& Rehabilitation, 18(3): 347-359. 
HEUDORF, U., SCHADE, M. (2014): Heat waves and mortality in Frankfurt am Main, Germany, 2003-2013: What effect do heat-health action plans and the heat warning system have? Zeitschrift für Gerontologie und Geriatrie, 47(6): 475-482.

HUTTER, H.-P., MOSHAMMER, H., WALLNER, P., LEITNER, B., KUNDI, M. (2007): Heatwaves in Vienna: effects on mortality. Wiener Klinische Wochenschrift, 119(7-8): 223-227.

KÁČEROVÁ, M., ONDAČKOVÁ, J., MLÁDEK, J. (2012): A comparison of population ageing in the Czech Republic and the Slovak Republic based on generation support and exchange. Moravian Geographical Reports, 20(4): 26-38.

KEATINGE, W. R. (2003): Death in heat waves. British Medical Journal, 327(7414): 512-513.

KENNEY, W. L., CRAIGHEAD, D. H., ALEXANDER, L. M. (2014): Heat waves, aging, and human cardiovascular health. Medicine and Science in Sports and Exercise, 46(10): 1891-1899.

KIM, Y.-M., KIM, S., CHEONG, H.-K., KIM, E.-H. (2011): Comparison of temperature indexes for the impact assessment of heat stress on heat-related mortality. Environmental Health and Toxicology, 26(1): e2011009.

KNOBOVÁ, V., HƯNOVÁ, I., MALÝ, M., BRANIŠ, M. (2014): Vliv vln vedra v létě 2003 a 2006 na úmrtnost obyvatel Prahy. Meteorologické Zprávy, 67(2): 33-39.

KOLLÁRIKOVÁ, P., SZOLGAY, J., PECHO, J. (2013): Dlhodobé zmeny vybraných charakteristík vín horúčav na Slovensku. Meteorologický Časopis, 16(2): 63-69.

KOPPOVÁ, K. (2011): Globálne zmeny atmosféry ako možná príčina mimoriadnych udalostí vo verejnom zdravotníctve. In: Klement, C. [ed.]: Mimoriadne udalosti vo verejnom zdravotníctve (pp. 42-53). Banská Bystrica, PRO.

KOSATSKY, T. (2005): The 2003 European heat waves. Eurosurveillance, 10(7-9): 148-149.

KOVATS, R. S., HAJAT, S. (2008): Health stress and public health: a critical review. Annual Review of Public Health, 29: 41-55.

KUCHCIK, M. (2006): Defining heat waves - different approaches. Geographia Polonica, 79(2): 47-63.

KUCHCIK, M., DEGÓRSKI, M. (2009): Heat- and coldrelated mortality in the north-east of Poland as an example of the socio-economic effects of extreme hydrometeorological events in the Polish Lowland. Geographia Polonica, 82(1): 69-78.

KUSENDOVÁ, D., TOMÁŠIKOVÁ, V. (2006): Population density - communes. In: Kusendová, D. [ed.]: Population Atlas of Slovakia: Change and distribution of population (pp. 14). Bratislava, Comenius University in Bratislava, Faculty of Natural Sciences.

KYSELÝ, J. (2004): Mortality and displaced mortality during heat waves in the Czech Republic. International Journal of Biometeorology, 49(2): 91-97.

KYSELÝ, J., HUTH, R. (2004): Heat-related mortality in the Czech Republic examined through synoptic and „traditional“ approaches. Climate Research, 25(3): 265-274.

KYSELÝ, J., KŘÍŽ， B. (2008): Decreased impacts of the 2003 heat waves on mortality in the Czech Republic: an improved response? International Journal of Biometeorology, 52(8): 733-745.
KYSELÝ, J., PLAVCOVÁ, E. (2012): Declining impacts of hot spells on mortality in the Czech Republic, 19862009: adaptation to climate change? Climatic Change, 113(2): 437-453.

LABUDOVÁ, L., ŠVEC, M., FAŠKO, P., VÝBERČI, D., TRIZNA, M. (in press): Dlhodobé zmeny vybraných charakteristík nadmerného tepelného stresu v lete na Slovensku. Meteorologický časopis.

LOWE, D., EBI, K. L., FORSBERG, B. (2011): Heatwave early warning systems and adaptation advice to reduce human health consequences of heatwaves. International Journal of Environmental Research and Public Health, 8(12): 4623-4648.

MARTIELLO, M. A., GIACCHI, M. V. (2010): High temperatures and health outcomes: A review of literature. Scandinavian Journal of Public Health, 38(8): 826-837.

MATZARAKIS, A., MUTHERS, S., KOCH, E. (2011): Human biometeorological evaluation of heatrelated mortality in Vienna. Theoretical and Applied Climatology, 105(1-2): 1-10.

MLÁDEK, J., KÁČEROVÁ, M. (2008): Analysis of population ageing in Slovakia: time and regional dimensions. Geografický časopis, 60(2): 179-197.

MONTEIRO, A., CARVALHO, V., OLIVEIRA, T., SOUSA, C. (2013): Excess mortality and morbidity during the July 2006 heat wave in Porto, Portugal. International Journal of Biometeorology, 57(1): 155-167.

MORABITO, M., PROFILI, F., CRISCI, A., FRANCESCONI, P., GENSINI, G. F., ORLANDINI, S. (2012): Heatrelated mortality in the Florentine area (Italy) before and after the exceptional 2003 heat wave in Europe: an improved public health response? International Journal of Biometeorology, 56(5): 801-810.

MORRIS, J.A., GARDNER, M. J. (1988): Calculating confidence intervals for relative risks (odds ratios) and standardized ratios and rates. British Medical Journal, 296(6632): 1313-1316.

MUTHERS, S., MATZARAKIS, A., KOCH, E. (2010a): Climate change and mortality in Vienna-A human biometeorological analysis based on regional climate modeling. International Journal of Environmental Research and Public Health, 7(7): 2965-2977.

MUTHERS, S., MATZARAKIS, A., KOCH, E. (2010b): Summer climate and mortality in Vienna - a human biometeorological approach of heat-related mortality during the heat waves in 2003. Wiener Klinische Wochenschrift, 122(17-18): 525-531.

OPOPOL, N., CROITORU, C., OVERCENCO, A., PANTEA, V., CRUDU, P. (2012): Decese suplimentare în Republica Moldova în vara neobişnuit de caldă a a. 2007. Analele Ştiinţifice ale USMF „N. Testemiţanu”, 13(2): 163-166.

OUDIN ÅSTRÖM, D., FORSBERG, B., ROCKLÖV, J. (2011): Heat wave impact on morbidity and mortality in the elderly population: A review of recent studies. Maturitas, 69(2): 99-105.

OVERCENCO, A. (2010): Epidemiological study of mortality during hot summer of 2007 in the Republic of Moldova [in Russian]. Bulletin of the Academy of Sciences of Moldova: Medical Sciences, 6(5): 43-50. 
PÁLDY, A., BOBVOS, J. (2010): Health impacts of heat waves of 2007 in Hungary - background and experiences. In: Dincer, I. et al. [eds.]: Global Warming. Green Energy and Technology (pp. 629-642). Springer US.

PÁLDY, A., BOBVOS, J. (2012): Impact of heat waves on excess mortality in 2011 and 2012 in Hungary. Central European Journal of Occupational and Environmental Medicine, 67(2): 33-39.

PÁLDY, A., BOBVOS, J., VÁMOS, A., KOVATS, R. S., HAJAT, S. (2005): The effect of temperature and heat waves on daily mortality in Budapest, Hungary, 19702000. In: Kirch, W. et al. [eds.]: Extreme weather events and public health responses (pp. 99-107). Berlin Heidelberg, Springer.

PASCAL, M., LAAIDI, K., LEDRANS, M., BAFFERT, E., CASERIO-SCHÖNEMANN, C., LE TERTRE, A., MANACH, J., MEDINA, S., RUDANT, J., EMPEREURBISSONET, P. (2006): France's heat health watch warning system. International Journal of Biometeorology, 50(3): 144-153.

PECHO, J., FAŠKO, P., LAPIN, M., KAJABA, P., MIKULOVÁ, K., ŠŤASTNÝ, P. (2010). Extrémne atmosférické zrážky na jar a na začiatku leta 2010 na Slovensku. In: Meteorologický časopis. 13(2-3): 69-80.

PLAVCOVÁ, E., KYSELÝ, J. (2014): Effects of sudden air pressure changes on hospital admissions for cardiovascular diseases in Prague, 1994-2009. International Journal of Biometeorology, 58(6): 1327-1337.

REVICH, B. A. (2011): Heat-wave, air quality and mortality in European Russia in summer 2010: preliminary assessment [in Russian]. Human Ecology, 7: 3-9.

ROBINE, J.-M., CHEUNG, S. L.K., LE ROY, S., VAN OYEN, H., GRIFFITHS, C., MICHEL, J.-P., HERRMANN, F. R. (2008): Death toll exceeded 70,000 in Europe during the summer of 2003. Comptes Rendus Biologies, 331(2): 171-178.

ROBINSON, P. J. (2001): On the definition of a heat wave. Journal of Applied Meteorology, 40(4): 762-775.

SAHA， M. V., DAVIS, R. E., HONDULA, D. M. (2014): Mortality displacement as a function of heat event strength in 7 US cities. American Journal of Epidemiology, 179(4): 467-474.

SHAPOSHNIKOV, D., REVICH, B., BELLANDER, T., BERO BEDADA, G., BOTTAI, M., KHARKOVA, T., KVASHA, E., LEZINA, E., LIND, T., SEMUTNIKOVA, E.,
PERSHAGEN, G. (2014): Mortality related to air pollution with the Moscow heat wave and wildfire of 2010. Epidemiology, 25(3): 359-364.

SHERIDAN, S. C., KALKSTEIN, L. S. (2004): Progress in heat watch-warning system technology. Bulletin of the American Meteorological Society, 85(12): 1931-1941.

SOBÍŠEK, B. [ed.] (1993): Meteorologický slovník výkladový a terminologický. Praha, Academia.

STANOJEVIĆ, G., STOJILKOVIĆ, J., SPALEVIĆ, A., KOKOTOVIĆ, V. (2014): The impact of heat waves on daily mortality in Belgrade (Serbia) during summer. Environmental Hazards, 13(4): 329-342.

STATISTICAL OFFICE OF THE SLOVAK REPUBLIC (2014): RegDat - regional statistics database. [online] [cit. 02.10.2014] Available at http://px-web.statistics.sk/ PXWebSlovak/index en.htm

ŠPROCHA, B., ŠÍDLO, L., BURCIN, N. (2015): Úroveň úmrtnosti na Slovensku a v Česku v európskom pohlade. Geografický Časopis. 67(1): 25-43.

ŠTVRTINOVÁ, V., KOLESÁR, J., ZVONÁR, J., ČABAJOVÁ, Z., WIMMER, G., PAPP, I. (1990): Vztah smrtel'nej embólie plúc $\mathrm{k}$ náhlym zmenám počasia. Praktický lékař (Praha). 76(2): 47-50.

TOULEMON, L., BARBIERI, M. (2008): The mortality impact of the August 2003 heat wave in France: Investigating the 'harvesting' effect and other long-term consequences. Population Studies, 62(1): 39-53.

URBAN, A., KYSELÝ, J. (2014): Comparison of UTCI with other thermal indices in the assessment of heat and cold effects on cardiovascular mortality in the Czech Republic. International Journal of Environmental Research and Public Health, 11(1): 952-967.

VANECKOVA, P., NEVILLE, G., TIPPETT, V., AITKEN, P., FITZGERALD, G., TONG, S. (2011): Do biometeorological indices improve modeling outcomes of heat-related mortality? Journal of Applied Meteorology and Climatology, 50(6): 1165-1176.

YU, W., MENGERSEN, K., WANG, X., YE, X., GUO, Y., PAN, X., TONG, S. (2012): Daily average temperature and mortality among the elderly: a meta-analysis and systematic review of epidemiological evidence. International Journal of Biometeorology, 56(4): 569-581.

ZANINOVIĆ, K., MATZARAKIS, A. (2014): Impact of heat waves on mortality in Croatia. International Journal of Biometeorology, 58(6): 1135-1145.

Initial submission 4 December 2014, final acceptance 28 August 2015

Please cite this article as:

VÝBERČI, D., ŠVEC, M., FAŠKO, P., SAVINOVÁ, H., TRIZNA, M., MIČIETOVÁ, E. (2015): The effects of the 1996-2012 summer heat events on human mortality in Slovakia. Moravian Geographical Reports, 23(3): 57-69. DOI: 10.1515/mgr-2015-0018. 